\title{
Za prof. dr. Hanou Voisine-Jechovou
}

\author{
Ivo Pospíšil (Brno)
}

Z Paříže přišla nedávno smutná zpráva. V požehnaném věku 93 let zemřela 21. 6. 2020 v nemocnici Paula Brousse ve Villejuif na jižním předměstí Paříže, asi osm kilometrů od městského centra, profesorka české literatury na Sorbonně, rytířka Ř́du čestné legie Hana Voisine-Jechová (nar. 19. 4. 1927 v Humpolci). Poslední rozloučení proběhlo 1. 7. 2020 v katolickém kostele Saint-Cyr Sainte-Julitte.

„Nikde nejsou tak krásné bř́zky jako na Vysočině, ale já jsem tady žít nemohla." V této větě se koncentruje těžký, ale plodný život české polonistky, slavistky a budovatelky francouzské bohemistiky, autorky dějin české literatury pro francouzského i českého čtenáře, překladatelky a české a francouzské prozaičky.

Hana Voisine-Jechová se narodila 19. 4. 1927 v Humpolci. Její otec byl za války zatčen a v Terezíně zemřel. Po studiu FF UK (čeština, francouzština) a sňatku s důstojníkem Československé armády Vladimírem Jechem pracovala nejprve ve Státním pedagogickém nakladatelství v Praze, od poloviny padesátých let minulého století pracovala na Univerzitě Palackého v Olomouci. Postupně se stala nejen znalkyní polské literatury, ale také renomovanou překladatelkou do češtiny a francouzštiny. Po dalších potížích s kandidátskou prací a habilitací se nakonec habilitovala ve Varšavě roku 1966. Na sklonku šedesátých let dostala pozvání na Sorbonnu k přednáškovému kurzu, v roce 1972 zde získala doktorát, v roce 1973 se však na naléhání rodiny vrátila, ale kvůli dalším potížím přijala novou nabídku francouzské vlády a odešla do Francie podruhé (její matka musela vycestovat s ní; současně ztratila československé občanství, rozvedla se a začala působit nejprve na univerzitě v Tours, později i na Sorbonně). Zde se jí roku 1982 podařilo prosadit a založit bohemistiku jako samostatný obor. V roce 1984 se podruhé provdala za profesora Jacquese Voisinea (1914-2001), špičkového, světově proslulého komparatistu a slavistu, který spolu s Reném Étiemblem (1909-2002) a Reném Wellkem (1903-1995) modifikoval metodologii této disciplíny, překladatele, autora slavné knihy J.-J. Rouseeau v Anglii v epoše romantismu (J.-J. Rousseau en Angleterre a l'époque romantique, 1956). Manželská spolupráce přinesla mimořádné tvůrčí plody, mimo jiné také již zmíněné dějiny české literatury (viz dále), i když - podle jejího svědectví - to nebylo jednoduché a musela překonávat někdy absurdní překážky osobního rázu. Prof. Voisine-Jechová napsala řadu knih, jež našly př́íznivou odezvu spíše než u nás v jiných zemích - kromě Francie - zejména v jejím milovaném Polsku, kam byla do poslední doby zvána na četné vědecké konference. Brněnská slavistika navázala s prof. Voisine přátelské kontakty - hlavně zásluhou manželů Zelenkových ke konci devadesátých let 20. století, kdy jsem se s ní setkával na různých vědeckých 
akcích a psal jsem o jejích studiích. ${ }^{1}$ Od té doby s námi udržovala pravidelné styky, byla několikrát na různých našich mezinárodních vědeckých setkáních, např. na konferenci o střední Evropě, na česko-slovenské konferenci, na kongresu českých slavistů, publikovala v našich periodikách a také recenzovala naše práce. ${ }^{2}$ Její studie slavistické, polonistické a obecně komparatistické zůstanou trvalou hodnotou mezinárodní literárněvědné slavistiky, polonistiky a komparatistiky. Dodávat k tomu, že byla členkou řady mezinárodních vědeckých organizací, např. Mezinárodní asociace komparatistů, činitelkou proslulého francouzského slavistického časopisu Revue des études slaves a dalších by bylo vožením sov do Athén. Hana Voisine-Jechová patřila k těm literárním vědcům, kteří soustavně psali i beletrii - tak se stala francouzskou a českou prozaičkou (pod dívčím jménem Hana Sánerová). Jak dosvědčují její vyjádření pro naše média, měla vždy velmi samostatné názory: to byl i jeden z důvodů, proč u nás v jistých kruzích nenašla její práce vědecká a organizační ve prospěch českého jazyka a literatury, světové bohemistiky a české kultury kladnou odezvu. Doma není člověk prorokem, a odtud i její výrok o vysočinských břízách. Trvalé místo v slavistice zaujala její kniha o Juliuszi Słowackém v české literatuře ${ }^{3}$ do české a mezinárodní slavistiky, polonistiky a obecně translatologie se zapsala překlady klíčových děl světových autorů: překládala Adama Mickiewicze, Henryka Sienkiewicze, přeložila slavnou sbírku povídek Bruna Schulze Skořicové krámy, napsala francouzskou knihu o Karlu Hynku Máchovi, přeložila Popely Stefana Żeromského, do francouzštiny Durychův Rekviem a další překlady, antologie a řadu větších i drobnějších studií, z litevského originálu přeložila epos Ročni doby (Metai, vzniklo asi v devadesátých letech 18. století, vyšlo až 1818) Kristijonase Donelaitise (1814-1880), přeložila také slavnou knihu Romana Ingardena O poznáváni literárního díla (1967, z polštiny, s doslovem Jana Patočky), německá verze Das literarische Kunstwerk (Halle, 1931) vyšla česky v překladu Antonína Mokrejše roku 1989. Bez její pomoci se neobešel ani francouzský překlad Komenského Labyrintu a lusthauzu srdce. Jejím klíčovým dílem jsou Images de la Bohème dans les lettres: reciprocité culturelle des Français, Tchèque et Slovaques (vyšlo na Sorbonně, 2004).

1 Viz naše pojednání: Česká literatura a jeji mezinárodni souvislosti (K českému vydání knihy Hany VoisineJechové Dějiny české literatury). Slavica litteraria 11, 2008, č. 1, s. 107-114; K směrově personalisticko-areálovým a komparativně kulturologickým dějinám národni literatury (Nad Ruskou moderní literaturou Milana Hraly a Dějinami české literatury Hany Voisine-Jechové). In: Od teorie jazyka k praxi komunikace. Sborník prací členů Katedry českého jazyka a literatury. Eds. Daniel Bína - Miloš Zelenka. České Budějovice: Pedagogická fakulta, Jihočeská univerzita, 2007, s. 19-30; Chvála klasické komparatistiky a jejích přesahů (Hana VoisineJechová: Spojrzenia komparatystyczne z różnych stron). Slavica litteraria 19, 2016, č. 2, s. 223-225.

2 Viz např. její recenze: POSPÍŠIL, Ivo - ZELENKA, Miloš: René Wellek a meziválečné Československo: ke kořenům strukturálni estetiky ( $\mathrm{R}$. W. et la Tchécoslovaquie entre les deux guerres: aux racines de l'esthétique structurelle). Brno: Masarykova univerzita v Brně, 1996 (Hana Voisine-Jechova). Revue des études Slaves, tome soixante-dixième, fascicule 2, Paris 1998, s. 503; POSPÍŠIL, Ivo: K teorii ruské literatury a jejim souvislostem. Spisy Masarykovy univerzity v Brně, Filozofická fakulta, č. 413. Brno: Munipress, 2013 (Hana Voisine-Jechova, Université Paris-Sorbonne). Revue des études slaves, tome quatre-vingtcinquième, fascicule 4, Pensée et culture en Pologne XX-XXI siècles, s. 777-779.

3 JECHOVÁ, Hana: Básnický obraze v dílech Julia Stowackého. Praha: Academia, 1966. 
Kardinální význam mají její Dějiny české literatury ve francouzské i české podobě4: původcem českého vydání původního francouzského originálu je Aleš Haman. Tato edice je velmi užitečná z řady důvodů. Na prvním místě stojí ten obligátní: pohled zvnějšku, kniha koncipovaná Češkou, ale po potřeby francouzského čtenáře, může vrhnout ostřejší světlo na vývoj české literatury a ukázat ji v evropském a světovém kontextu. Voisine-Jechová vykládá českou literaturu v symbiózách a osudových dvojicích, dílem komplementárních, dílem antinomických, jak to dějiny přinášely: Češi - Němci, Češi - Slované, Češi - střední Evropa, Češi - Rakousko, Češi - Slováci, Češi - Poláci, jen stopově Češi - Rusové nebo Češi - Mad’aři. Její pojetí současně zvýrazňuje to, co z této podivuhodné reality vyplývá, totiž často groteskní a absurdní vývojové etapy a epizody: jezuité, kteří bojují za češtinu a bádání o češtině, německy píšící čeští vlastenci a celý křivolaký politicko-kulturní vývoj ve 20. století s jeho levicovostí, katolickou a protestantskou orientací, s kulturně politickou činností emigrace. Autorka současně ve stopách dualit Reného Wellka ukazuje na duální vývoj české literatury v rovině spirituální - materialistický, katolický - protestantský, levicový - pravicový. Ukazuje se, že to, co je silou české literatury, je vytváření balance těchto všech výše uvedených antinomií a komplementárních dualit: převaha jednoho pólu, resp. likvidace pólu protikladného vždy vedla k oslabení (někdy až katastrofálnímu) esteticko-duchovní funkce české literatury, nebot’ jejím základním rysem nepřestává být ono prostupování a vzájemnost v nejširším slova smyslu: možná právě proto si někteří myslí, že má i mimořádné evropské poslání. Celistvost české literatury vytváří především spodní proud kontinuity, která vychází z uvedených duálních kořenů; zdá se, že něco zásadně tuto literaturu mění, ale obvykle tomu tak není: následný vývoj vrátí evoluční kyvadlo zase zpět, ale ovšem nikoli do stejného místa. Síla proporcionality, jistá podoba harmonie provází český literární vývoj od středověku po dnešek, stejně jako kontrastní tendence a protikladné postavy, z nichž mnohé se objevují i ve žhavé současnosti; to zajištuje české literatuře nutnou dávku plurality a tím i vývojový dynamismus: i v dobách otevřeného politického nebo politicko-mediálního útlaku nebo potlačování nějaké vývojové, ideově tvarové tendence nebo osobností se tyto tendence nebo osobnosti - pokud měly nebo mají estetický význam - znovu vynoří, nezaniknou, dokládajíce tak známou Bachtinovu tezi o velkém čase dějin a vzkřríšení každého významu vloženého do literatury. Pro nejstarší období vývoje české literatury našla autorka velmi štastně to, co bylo vždy pro českou komparatistickou slavistiku typické: nepřímo totiž navazuje na mediteránní koncepci Franka Wollmana, která směřuje proti umělému rozštěpení Evropy, v podstatě dědictví Imperia romana, na tzv. Východ a Západ, odkazujíc k společným středomořským kořenům civilizačním a kulturním; jde zejména o malou podkapitolu Meze slovanské mise. I když vývoj českých zemí nakonec směřoval k západní tradici Pax romana, východní stopa tu zůstala natrvalo, byt jen jako tenký proud, jenž někdy sílí, jindy slábne. Za jádro specifického českého literárního vývoje pokládá Voisine-Jechová jednak samostatnou slovanskou kapitolu, jednak české plodné stýkání s cizími kulturami: kromě slovanské, resp. staroslověnské, především s latinskou a německou s vrcholem v české gotice 14. století, zejména za vlády Karla IV., kdy kulminuje český podíl na vývoji

4 Pův. francouzsky: Histoire de la littérature tchèque. Paris: Fayard, 2001; Dějiny české literatury. Přel. Aleš Haman. Jinočany: H\&H, 2005. 
evropské (křestanské) kultury a literatury. Nicméně i husitství chápe autorka jako přirozené vývojové vyústění, jako radikální projev všeobecné evropské krize dosavadních hodnot, resp. jejich devalvace. Měřítkem důležitosti té které kulturní epochy jsou postavy, které dosáhly evropského věhlasu: je to nejen Jan Hus, ale také Petr Chelčický, své místo tu najde i mýtus Jan Žižky a Prokopa Holého, z literárních žánrů pak teologická reflexe, list či poslání, didaktický spis, duchovní píseň. Nakolik bylo husitství a jeho duchovní prameny jako hnutí předreformační syceno z východních zdrojů cestou známých asijjkých herezí jdoucích od východu na západ počínaje dualismem beroucím asi počátek v buddhismu, tedy manicheismem, zoroastrismem přes gnósi dál na západ k balkánskému bogomilství a ještě dále $\mathrm{k}$ albigenským a zpět na východ $\mathrm{k}$ hranicím Čech k valdenským, zůstává jen hypotézou, k níž se v 19. století často kontroverzně obraceli východoslovanští pravoslavní, resp. slavjanofilové - u nás se to většinou odmítalo, ačkoli, myslím, až příliš nediferencovaně. Nicméně ani vývoj přerušený husitskou protireformací nestojí mimo autorčinu pozornost: nicméně již názvy kapitol či podkapitol dává najevo převahu českého humanismu nad českou renesancí, v jejímž rámci tradičně zmiňuje Hynka z Poděbrad a další. Možná zde autorka méně výrazně zachytila epochální změnu po zavedení knihtisku - i z hlediska dnešních možností reprodukovatelnosti to byla změna vskutku klíčová, zásadní a mamutí a podepsala se na celém charakteru literární komunikace. Nepochybně z hlediska světovosti stojí v centru její pozornosti hnutí českých či moravských bratří, kralický překlad bible, dílo Jana Blahoslava a jeho předchůdců. Za vrchol tohoto složitého, přerývaného kulturního vývoje pak pokládá kosmopolitismus na dvoře Rudolfa II. a pak osobnost Jan Amose Komenského, co se dodnes často nijak zvlášt’ nezdůrazňuje, že byl spjat s českými zeměmi, s češtinou a českou literaturou (Comenius). Autorka mu věnuje v podstatě třináct stran textu, správně zdůrazňujíc nejen jeho význam učenecký, ale zejména estetický, umělecký. Za další vrchol české literatury pokládá přirozeně dobu barokní zcela v souladu s dnešním poznáním a ukazuje na vývoj k osvícenství: postihuje tím dynamické pnutí, které nabízelo alternativu „měkkého“ osvícenství, stejně jako „měkkého“ romantismu, jež by tolik nepopíraly předcházející vývoj, a my víme, že spodním proudem tu kontinuita přerušena stejně zcela nebyla. Pro podrobnější výklad odkazuji ke svému již uvedenému pojednání, patrně jednomu z nemnoha, jež knihu hodnotí jednoznačně kladně, i když s drobnými výhradami interpretačního rázu. Za klíčové výklady považuji 19. století, uvádění německého, ale i širšího mezinárodního kontextu české literatury, jež je ukázána jako jev stojící - zcela ve Wollmanově a Krejčího duchu - na křižovatkách evropského kulturního vývoje.

Kniha Hany Voisine-Jechové vydaná původně pro francouzského čtenáře a pak dobře přeložená a upravená i pro potřeby čtenáře českého, aniž by se setřel základní charakter původního pojetí, je velmi dobře napsaným a kvalitně koncipovaným dílem. Je to kniha, která usiluje ukázat českou literaturu a „filozofii“ jejího vývoje jako integrální součást evropského a světového vývoje, a to je i dnes v této intenzitě poměrně vzácné.

Dvakrát jsem měl tu čest recenzovat její skvělé prózy, a to českou (Zlomky nepravého deniku, 2013) a francouzskou (Quelques morceaux d'images et de pensées, 2017). ${ }^{5}$ Obě prózy sty-

5 Próza dnešního času, reflexe a samota (SÁNEROVÁ, Hana: Zlomky nepravého deníku. Praha: Nakladatelství Andrej Štastný, 2013). Almanach Nitra 2013 (14. ročník). Eds. a vedeckí red. Jozef Vladár - Natália 
lizované jako deníkové zápisy představují vlastně reflexe české intelektuálky v jinojazyčném prostředí, které si dokonale osvojila a s nímž se sžila, jež se pohybuje mezi Paříží a Prahou, francouzským a českým prostředím, ale i mezi západní a střední Evropou, ale tato nezakotvenost není dána jen její emigrací v sedmdesátých letech 20. století: ve vysokém věku stojí na zlomu epoch a tuto situaci si dobře uvědomuje, i když řeší především své vztahy a vlastní osamělost. Exil však přesto zůstává klíčovým problémem, jakousi bránou do nového světa, v němž se všichni ocitáme a jemuž nerozumíme: „Člověk je cizinec, když nežije v zemi, kde se narodil, v zemi svých předkư a lidi mu blizkých, tam, kde se mluví jeho mateřským jazykem. Exil je tragický, nebot člověk miluje misto, kde se narodil a které byl nucen opustit. Je přrirozené, že miluje svou vlast, musí ji milovat. Mám se stydět za to, že tyto pocity nesdilim? Ale nesdilím je skutečně? A přisuzuji je druhým lidem neoprávněně? Nelze si to ověrít ${ }^{\text {" }}$ (s. 7). Podstatou dnešního světa je kult technologií, ale už není zřejmé, zda člověku více prospívají, nebo škodí: „A potom - někdy se mi zdá, že všechno je dèláno jaksi pro lidstvo (ale jak definovat lidstvo) - ne pro člověka. V té záplavě věci neni misto pro to, co je subjektivni, jedinečné. Literatura se proměnila v konzumni zboži. Knižka se prěčte, někdy se ani nedočte a zahodi se" (s. 15). Umění však také není všelék, často je chladné a sociálně lhostejné: „Ale zdá se mi, že je v nich málo intimního kouzla, jejich krása je někdy skoro nelidská, jako třeba u vily Tugendhat v Brně nebo v jedné cásti Tokia, kde se týč́ pruizračné, svítivé mrakodrapy, které se podobaji spiše věžim jakýchsi svatyñ než domům pro lidské tápáni" (s. 16). To, co fragmentárními pseudodeníky Hany Sánerové prostupuje skrz naskrz, je samozřejmě literatura. Jane Austenová, Henry Fielding, Fjodor Dostojevskij, Franz Kafka, Henri Bergson, Virginia Woolfová... Zajímavá je, i když je to tu spojeno s vědeckým projektem, preference 18. století, osvícenství, věku rozumu; asi to nebude náhoda, jež nutí myslet na známý Mandelštamův esej, jenž se však týkal století devatenáctého, kde přesně předvídá - stejně jako souběžně s ním Nikolaj Berd'ajev - charakter 20. století a hlavně jeho konec a přelom 20. a 21. věku, a tedy naši dobu (koluje v ní prý těžká krev starých civilizací, snad babylónské a asyrské - chce se říci: i s jejich hrůzami a temnou iracionalitou): encyklopedisté budou prý pro nás v té době jako oheň Prométheův.

Je tu i dost sexuality, spíš ovšem v podobě zdrženlivé, neosobní, jako úvahy, mj. o sexuální otevřenosti, promiskuitě, homosexualitě; vícekrát se opakují názory o nepochopitelnosti dnešního světa (lidí, kteří si myslí, že do něho nepatří, stále přibývá). Autorka hledá „vztahy”, často k ženám, přátelství a vnitřní pochopení.

I když v titulku této pozoruhodné prózy je slovo „zlomky”, kompozice svazku je celistvá a hluboce promyšlená: spočivá na úchytných bodech, ukotvených na uměleckých detailech: babiččina půda se starými časopisy jakoby z jiného světa dávných obrozenců, Bouloňský lesík se stíny lidí, kteří se tu procházívali, všudypř́ítomný Gombrowicz a jeho Polsko; idée fixe je souboj s československou tajnou policií a představa, že tito a podobní lidé tu vládnou dosud. A úvahy o smrti a nesmrtelnosti a samozřejmě vyrovnávání se

Muránska. Nitra: Mesto Nitra - Nitrianska odbočka Spolku slovenských spisovatelov - Filozofická fakulta Univerzity Konštantína Filozofa v Nitre, 2014, s. 293-296; Tomuto svètu už nerozumím... (SÁNEROVÁ, Hana: Quelques morceaux d'images et de pansée. Essai. Paris: Les Éditions La Bruyère, 2017). Proudy, 2018, č. 1. http://www.phil.muni.cz/journal/proudy/filologie/recenze/2018/1/pospisil_tomuto_svetu_ uz_nerozumim.php\#articleBegin. 
s vírou, Bohem, desaterem, náboženstvím (Z dětství si vzpomínám, jak v době vypuknuvší ateistické kampaně po tzv. mad’arských událostech roku 1956, jak se tomu kdysi eufemisticky ř́kalo, přesněji v roce 1958, museli zaměstnanci podepisovat „kulaté“ prohlášení, že jsou „vyrovnáni s náboženskou otázkou“; jak se např. učitelé báli, aby doma neměli náboženské symboly, např. kříže, za které by je jejich kolegové mohli udat školským úřadům - to vše nezačalo již po roce 1948, to ještě komunisté na venkově křtili své děti a chodili na „boží těla“ - protináboženské čistky, zejména na vysokých školách v roce 1958 vedli často obroditelé z roku 1968). Pro intelektuála je problém víry, Boha, nikoli církví, velmi obtížný, ale současně klíčový. Deník je vždy samomluvou, ale i skrytým dialogem: se sebou, ale i s jinými, hypotetickými výroky a postavami. Koneckonců celý svazek Hany Sánerové končí větou: „Proč se stále jen ptát? Kam to vede?...“ (s. 190).

Všeobecným ekvivalentem je v knize soumrak, stmívání, tedy pohyb k zániku; to je otázka konečnosti lidského života a zlomu epoch a konce naší civilizace. Co to vlastně Hana Sánerová říká na samém sklonku své knihy? „Stát měl kdysi povinnost chránit život, majetek a čest občanů. Platí to ještě dnes? Nebo pojem cti už vymizel? Pouze v Čechách? Nebo všude? Stát, který nerespektuje občany, nemůže být respektován, lidé se v něm nerespektuji navzájem, stávaji se cizinci... A pak mohou žít jako cizinci kdekoli. K takovému státu neni nutno patřit, neni to ani žádouci - a určitě neprìcházi v úvahu, mít ho rád'. Říám si to skoro se zadostiučiněním a je mi podivnĕ, rezignovaně smutno. Ospravedlňuji si tím svou emigraci, svou neschopnost nebo nechut’ obnovit si své bývalé občanstvi? Před očima se mi vynořuji jihočeské rybniky, jedna socha na Karlově mostě, jedna ulička na Malé Straně... A několik lidí, s kterými mi tam bývalo dobře. Ale to byla moje rodná země - a ne stát s ideologiemi, které se stř́daji, v různých formách opakuji, zdánlivě mizi, a presto degraduji člověka. A kde jsou hranice mezi různými druhy nepravosti? Jedním z př́iznačných rysů naši epochy je asi jakýsi druh schizofrenie“ (s. 155).

Ve francouzské knize je více obecných zamyšlení, ale jsou tu i věci takříkajíc intimní, ale současně i hrdé osamění, na němž si autorka stále zakládá. Úvahy o tomto světě nejsou ani tu povzbudivé, rozpad tradičních struktur, které nejsou nahrazovány něčím jiným, stejně funkčním, rodina už neexistuje, hodnoty, jež vyznávala autorka a celé generace, už odešly do nebytí, ale něco přece jen zůstává, i když naděje zbylo málo. Svět jak jej znala, včetně Francie a Paříže, už neexistuje. Nakonec věta: „Le monde où j'ai vécu n'existe pas. Mes amis sont morts... Et moi? Ai-je encore quelque chose à faire?" (s. 208). Mám ještě něco dělat nebo: stojí to vủbec za to, má to nějaký smysl, když svět, v němž jsem žila, už neexistuje a moji přátelé jsou mrtví? Prózy Hany Voisine-Jechové/Sánerové jsou výtvory statečné, hrdé ženy, která vykonala velký kus práce. Je to výpověd' silná, je to konfese důstojná, ale smutná.

Hana Voisine-Jechová byla a je dítětem své doby, kterou pochopila a procítila z obou pólů: jednak jako ta, která se literaturou zabývá, jednak jako její tvưrkyně, jež cítí krizovost dnešního světa, jeho soumrak. Život nelehký, ale naplněný smysluplnou prací, jejíž výsledky přetrvají. 
prof. PhDr. Ivo Pospíšil, DrSc.

Ústav slavistiky

Filozofická fakulta, Masarykova univerzita

Arna Nováka 1, 60200 Brno, CZ

ivo.pospisil@phil.muni.cz

Toto dílo Ize užít v souladu s licenčními podmínkami Creative Commons BY-SA 4.0 International (https://creativecommons.org/licenses/by-sa/4.0/legalcode). Uvedené se nevztahuje na díla či prvky (např. obrazovou či fotografickou dokumentaci), které jsou v díle užity na základě smluvní licence nebo výjimky či omezení př́slušných práv. 
